\title{
Meteotsunamis produced by high frequency atmospheric pressure forcing
}

\author{
Li-Ching Lin $^{1}$ and Mao-Chang Liang ${ }^{1,2,3, *}$ \\ ${ }^{1}$ Research Center for Environmental Changes, Academia Sinica, Taipei City, Taiwan \\ ${ }^{2}$ Graduate Institute of Astronomy, National Central University, Taoyuan City, Taiwan \\ ${ }^{3}$ Department of Physics, University of Houston, Texas, U.S.A.
}

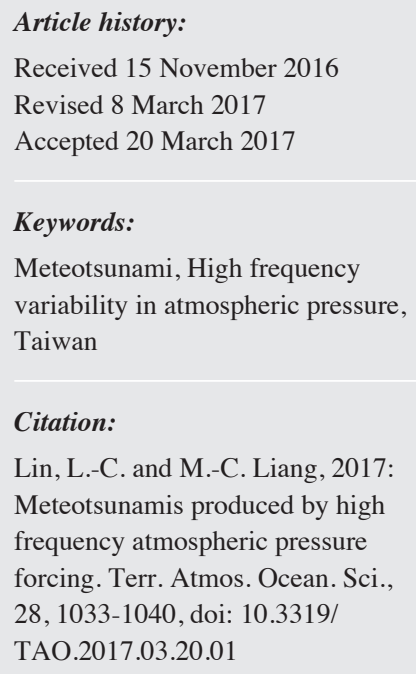

\begin{abstract}
Long-term and high resolution sea level data (2008 - 2014) have been analyzed to investigate the link between meteotsunamis and atmospheric pressure variability. The peak to peak amplitude of meteotsunamis at periods of $10-30$ min can be as high as $1.5 \mathrm{~m}$, approximately $70 \%$ of the tidal variation. Analysis shows that the correlation coefficient between high frequency oscillations in pressure $\left(>0.01 \mathrm{~min}^{-1}\right)$ and meteotsunamis can be up to $\sim 0.8$ in winter and spring seasons, supporting that atmospheric forcing is a most important driving force for generating meteotsunamis. One identified source during the period is the arrival of continental cold air masses, affecting the meteorology and subsequent meteotsunamis in Taiwan regions. The established correlation can then be used to predict and quantify the probability of meteotsunamis in operational forecast products and long-term climate simulations.
\end{abstract}

\section{INTRODUCTION}

For years, fishermen working in Taiwan waters have noticed abnormal changes on sea level in relation to severe weather. In winter and spring seasons, unusual events were recorded inside harbors with incident waves at tsunami-like periods. In reviewing historical reports, such events are frequent but catastrophic ones are rather rare in Taiwan. Such tsunami-like waves caused by meteorological forcings are known as meteotsunami. Sea level variations at periods up to tens of minutes, fluctuating with large amplitudes in response to atmospheric perturbation, can cause damages to coastal regions at a degree similar to tsunami waves (Monserrat et al. 2006). Destructive meteotsunamis have been reported in Vela Luka Bay of the Island of Korčula (Orlić 1980), Široka Bay of the Island of Ist (Šepić et al. 2009) in the Adriatic Sea, and Nagasaki Bay in Japan (Hibiya and Kajiura 1982); some of them could have a peak-to-peak amplitude more than $4 \mathrm{~m}$. Such waves result in boat damages inside bays and harbors and extensive flooding around the area.

To distinguish between tsunami and meteotsunami is

\footnotetext{
* Corresponding author

E-mail:mcl@rcec.sinica.edu.tw
}

difficult as both resemble the dynamics of incoming waves and may cause damages at a similar level. The former, however, could be more catastrophic, especially the generation and excitation through near-field seismic events. Therefore, identification between the two types of destructive waves is critical for preventing false alarms in tsunami warnings. In this work, we document the events which are not associated with major quakes or landslides but with mesoscale atmospheric perturbations (meteorology) across shallowshelf seas. For that, atmospheric forcing is the most likely external force to generate meteotsunamis in local and remote regions. Reports of extreme waves are attributed to some particular atmospheric forcings with sudden pressure changes in a shape-like form (Hibiya and Kajiura 1982; De Jong and Battjes 2004; Vilibić et al. 2004), high frequency pressure oscillations (Vilibić and Paklar 2006), and storm depressions (Thomson et al. 2007; Mecking et al. 2009).

One mechanism on enhancing meteotsunamis could be due to the activity of internal waves originated from remote distances (Wijeratne et al. 2010). Under some circumstances, meteotsunamis could be amplified through resonance effects, like the Proudman, Greenspan, and topographic resonances 
(e.g., Monserrat et al. 2006; Pattiaratchi and Wijeratne 2015). Initial enhancement of meteotsunamis could be caused by the Proudman resonance (Proudman 1953) at a shallow region, which describes the coincidence between the phase speed of such tsunami-like wave $(c=\sqrt{g h}$, where $g$ is the gravity acceleration and $h$ is the water depth in the region) and the traveling speed of barometric disturbances $(U)$. The wave can be theoretically amplified by as much as $\left(1-U^{2} / c^{2}\right)^{-1}$ but normally reaching an amplification factor of 5 or more by the barometric effect alone (e.g., Hibiya and Kajiura 1982).

On 29 - 30 January 2008, notable waves with a peakto-peak amplitude as high as $1.5 \mathrm{~m}$ were recorded at a small harbor of Taiwan (JU, referred in Fig. 1), and such large waves were also simultaneously reported at the harbors nearby in the northern Taiwan; two upset fishing boats were found for this event. Concurrently, a rapid change in pressure was observed by a number of barometers. From the report, the barometric effect thus is considered as an important factor responsible for the generation of meteotsunamis. In this work, we focus on the exploration of various meteorological forcings on the wave generation using the high resolution data collected in several locations along the coast of Taiwan between 2008 and 2014.

\section{OBSERVATIONS AND METHODS}

Sea level height has been recorded continuously at four tide gauge stations (JU, TP, KL, and WU; Fig. 1) with a sampling interval of $1 \mathrm{~s}$ since 2008. High resolution instruments (3000XDCR, Aquatrak) are deployed for tsunami detection and early warning of tsunami. Attempt was made to enhance the signal to noise ratio for the data by averaging the data for $15 \mathrm{~s}$ to reduce high frequency oscillations, followed by least squared harmonic analysis to remove tides (Foreman 1977). To link the variability in the derived ocean wave time series with meteorology, we performed power spectral density (PSD) analysis for the time series of interest, following Welch's method with $50 \%$ of overlapping and hamming window functions (Welch 1967). For this, the most relevant parameter, atmospheric pressure, from nearest meteorological sites was analyzed; atmospheric pressure data are recorded at a sampling interval of $1 \mathrm{~min}$. All data are available publicly from Central Weather Bureau, Taiwan (http://www.cwb.gov.tw). The two identified tsunamis originated at Chile in 2010 and Japan in 2011 have been removed from the datasets.

We first establish forcing-response relation between ocean waves and meteorology by analyzing the sea level data to check the correlation with the atmospheric pressure variation. Upon the detection of large waves, we examine the changing patterns of ocean waves and atmospheric pressures. We then utilize spectral source function analysis and compare the characteristics of the power spectra between the ocean waves and respective air pressures (Rabinovich
1997). This method allows ones to separate the local topography resonance and source region effects for tsunami-like waves in frequency domain. The spectral source function expresses the spectral ratio of the spectra, $R(\omega)=S_{o b s}(\omega) /$ $S_{b}(\omega)$, between tsunami-like oscillations, $S_{o b s}(\omega)$, and background, $S_{b}(\omega)$, where $\omega$ is the frequency, and the ratio is insensitive to local topography effects.

\section{RESULTS}

From the statistical analysis shown below, we found that meteotsunamis occur primarily in winter to spring seasons (December through April). This is because in these two seasons, northeastern monsoons largely control the meteorology of the region, causing high variability in pressure. As a result of forcing from the atmosphere due to changing meteorology, meteotsunamis could then be generated.

We examine all of the relevant events from 2008 2014. Three events, representatives of local changing meteorology, are selected to demonstrate the presence of meteotaunamis: 29 January 2008, 5 March 2009, and 16 February 2010 (Fig. 2). The peak-to-peak amplitude of the retrieved signals exceeding $1 \mathrm{~m}$ is found in the northern Taiwan, which is significant compared with the diurnal tide variation of the sea level. From analysis of atmospheric pressure, a clear abrupt drop is observed in the first event, pressure jump in the second, and high frequency pressure fluctuation at smaller amplitudes in the last. These three atmospheric pressure changes are caused by cold air masses coming from the Siberian Mongolia high, which are known to affect the region during the winter and spring seasons ( $\mathrm{Lu}$ and Chang 2009). Major characteristics of the perturbed meteorological phenomena are lower temperatures and higher sea level pressures, propagating from northern Asia to Taiwan region. Spectral and correlation analyses shown below clearly demonstrate the relation between the atmospheric forcing and ocean wave response.

Air pressure changes in association with meteotsunamis for the selected three events are shown in Fig. 2. On 29 January 2008 , a large meteotsunami occurred approximately at $1200 \mathrm{LT}$ and continued for $1.5-2 \mathrm{hrs}$ in the north area of Taiwan. Accompanied with the event was a reduction in atmospheric pressure. Meteotsunamis appeared mostly in JU and TP and followed closely with the filtered high frequency pressures or atmospheric pressure changing rates (see Fig. 2). In this work, we adopted spectral filtering technique to the meteorological and ocean wave data to examine the correlation between the generation of metotsunamis and changing meteorology. In addition, Šepić and Vilibić (2011)'s pressure changing rate approach which set a threshold of $1 \mathrm{hPa} / 5$ min for meteotsunami generation and strengthening was also compared, and we found that both of the methods performed similarly (Fig. 2; see also Fig. 3 below). The figure showed that the atmospheric perturbation propagated eastward at an 


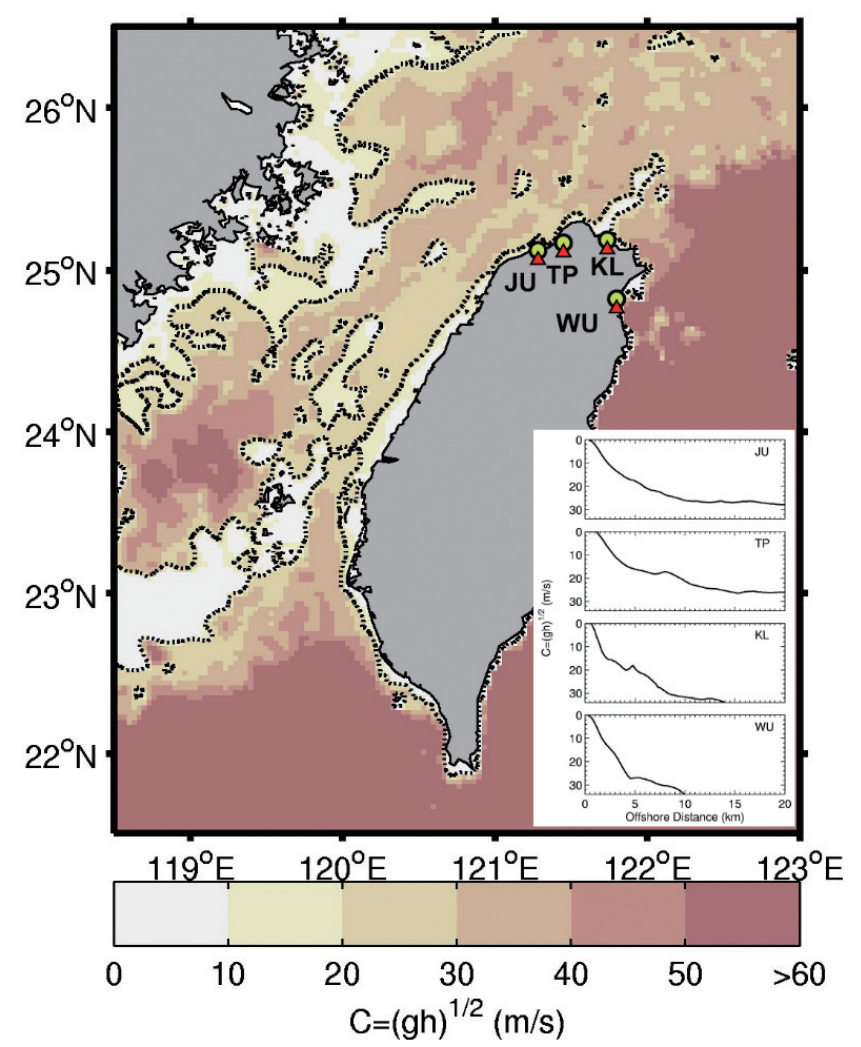

Fig. 1. Locations of the four tide gauge stations (shown by the circles): Jhuwei (JU), Taipei (TP), Keelung (KL), and Wushi (WU). Air pressure sensors (triangles) are sitting close to the tide gauges. The data are obtained from Central Weather Bureau during $2008-2014$. The ocean topography is shown by converting to the phase velocity of ocean waves. Dashed contour indicates the $20 \mathrm{~m} \mathrm{~s}^{-1}$. Insets: converted phase velocity from local topography at each location. (Color online only)
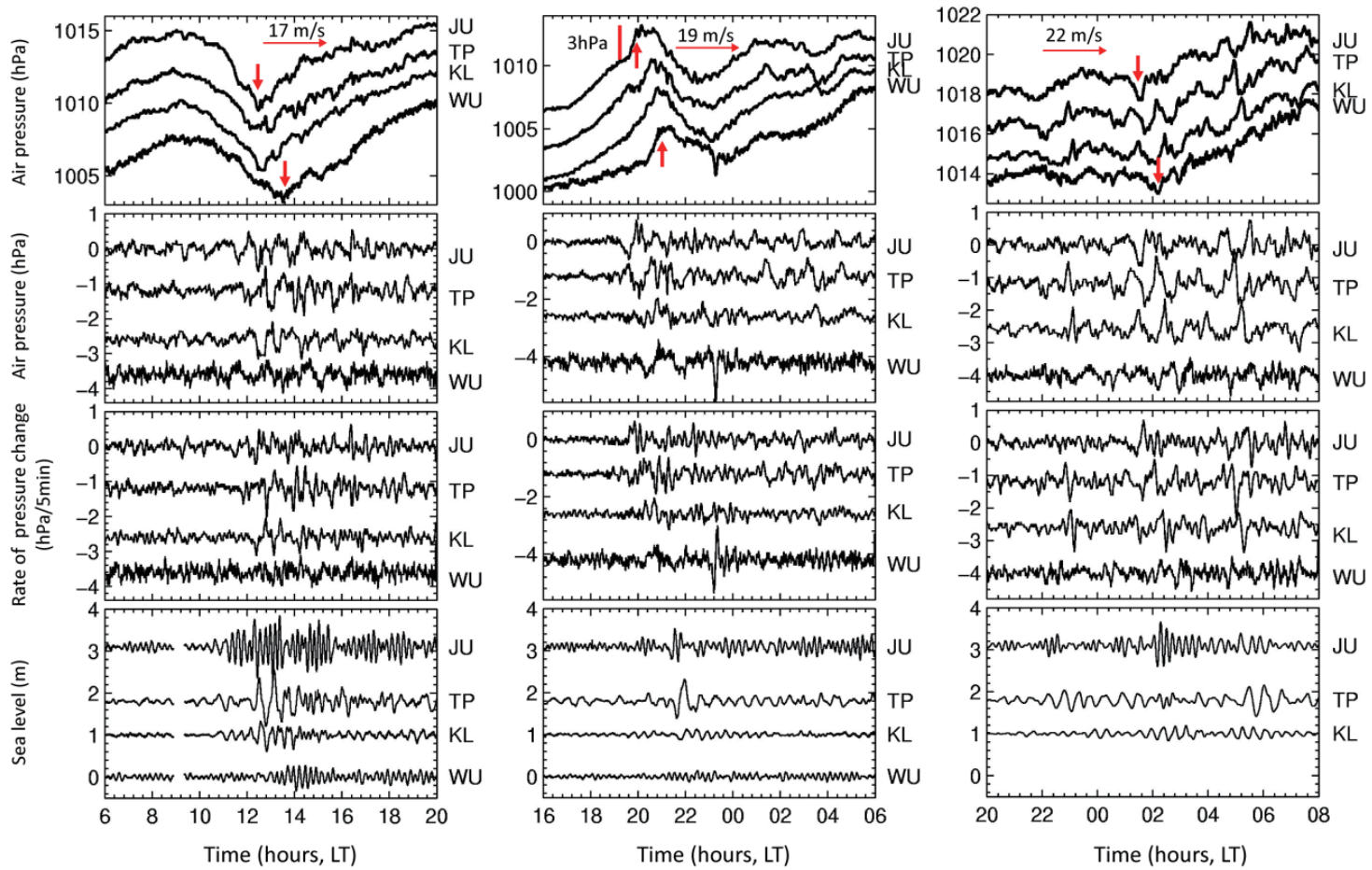

Fig. 2. Time series of atmospheric pressure, high frequency filtered pressure, pressure changing rate, and sea level for the three selected events on 29 January 2008, 5 March 2009, and 16 February 2010. LT indicates local time. The presented pressure changing rates are convolved by a 5-min running average window. The vertical arrows in the top panels label the arrival time of meteorology forcing. (Color online only) 

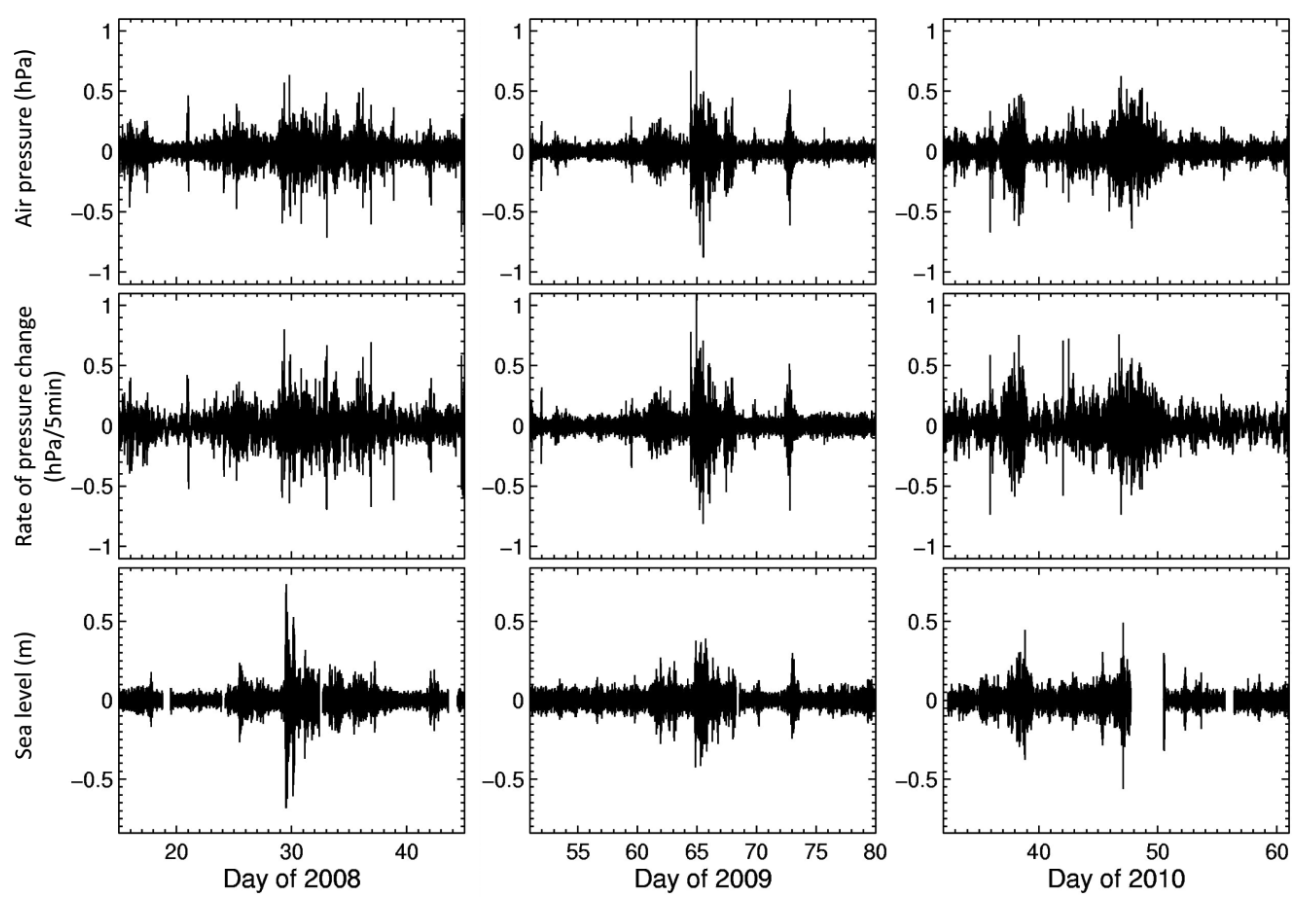

Fig. 3. Comparison between the filtered signals centered at the three aforementioned events in Fig. 2.

averaged traveling speed of $17 \mathrm{~m} \mathrm{~s}^{-1}$ from JU to WU. This traveling speed is close to the local ocean wave phase speed (Fig. 1), a condition which is required to explain the amplified meteotsunamis seen at JU. The retrieved peak-to-peak amplitude of the meteotsunamis at JU could be as much as $1.5 \mathrm{~m}$, about $70 \%$ of the tidal amplitude $(2.2 \mathrm{~m})$. We notice that the sea level responds to the atmospheric forcing fast; the amplitude decreases to less than $0.5 \mathrm{~m}$ when the forcing propagates away to the northeast part of Taiwan.

Similar forcing-response signature is also seen in 2009. Instead of sudden reduction in air pressure in the previous case, the event shows a jump of $\sim 3 \mathrm{hPa}$ in pressure in $30 \mathrm{~min}$. A persistent fluctuation in sea level appears right after the passage of the air pressure change. The estimated perturbation in pressure travels eastward at a speed of $19 \mathrm{~m} \mathrm{~s}^{-1}$, again close to the required criterion for the ocean waves to be amplified. In this case, the maximal variation recorded is $\sim 0.8 \mathrm{~m}$ at JU and TP and is less than $0.3 \mathrm{~m}$ at the other sites.

In addition to the aforementioned mechanisms of the generation of meteotsunamis triggered by a sudden jump and drop of atmospheric pressure, persistent high frequency oscillation in pressure can also result in meteotsunamis. An event occurred in 2010 demonstrates such an example (Fig. 2). Atmospheric pressure fluctuating at an amplitude less than $1 \mathrm{hPa}$ or a rate of air pressure change less than $1 \mathrm{hPa} / 5 \mathrm{~min}$ generates meteotsunamis that vary at an amplitude as much as 1.1 and $0.7 \mathrm{~m}$, respectively, at JU and TP. Similar to the previous two events, the pressure perturbation propagates eastward at $22 \mathrm{~m} \mathrm{~s}^{-1}$ from JU to WU. In reviewing all the above three events, we found that meteotsunamis occurred in close association with meteorology forcing traveling speed. For the near shore topography of the stations in the northern Taiwan, a barometric forcing traveling speed of $\sim 20 \mathrm{~m} \mathrm{~s}^{-1}$, a value close to the ocean wave phase speed around the region of interest, is needed to trigger and amplify the observed meteotsunamis.

To further examine the excitation of meteotsunamis by atmospheric pressure forcing, spectral energy distribution analysis is performed. Spectral analysis is applied to the sea level and atmospheric pressure data during the two-day duration of meteotsunamis. Spectral ratio is then utilized to show whether the meteotsunami generations are localized; 5 days of calm conditions for both parameters taken in 2008 are selected to represent background level. Figure 4 shows the PSDs of the selected meteotsunami events at JU. Two dominant signals at periods of 2.4 and $13.3 \mathrm{~min}$ are identified for sea level changes. For comparison, the background spectrum is also shown. The analysis shows that the signal at $2.4 \mathrm{~min}$ is the result of harbor resonance and/or infra-gravity waves based on non-linear transformation from ocean swell in the coast region (Herbers et al. 1995). The long period energy peak at $13.3 \mathrm{~min}$, however, is not associated with the harbor's characteristic dimensions. Remote sources outside the harbors are presumably responsible for the signal. The spectral analysis for atmospheric pressure demonstrated in Fig. 4 clearly suggest that during the period of meteotsunamis, the oscillation in pressure at frequencies higher than $\sim 0.01 \mathrm{~min}^{-1}$ becomes more energetic. Subsequent topography-affected frequency filtering and amplitude amplification result in magnification of ocean waves peaked at $\sim 13 \mathrm{~min}$, 


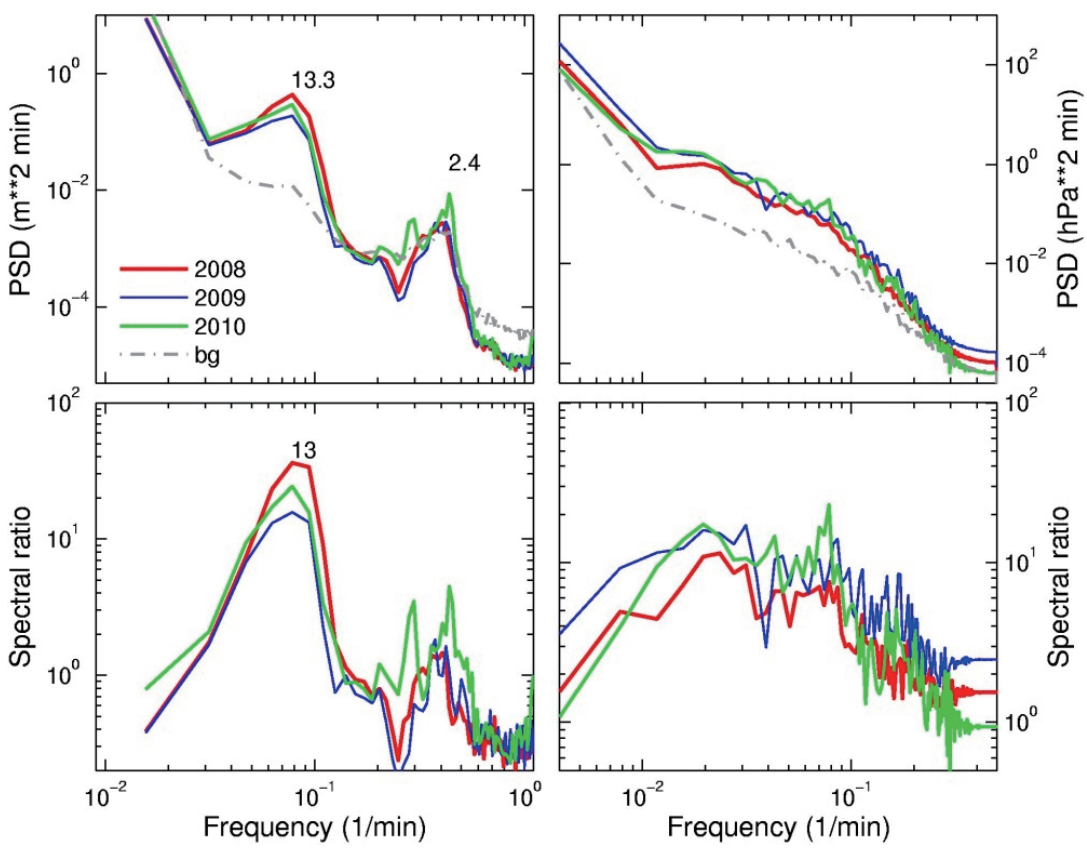

Fig. 4. Upper panels present the PSDs for the sea level (left) and air pressure (right) during occurrence of meteotsunamis. Bottom panels are the corresponding spectral ratios. For comparison, the background spectra are also shown. (Color online only)

seen at the sampling location. Similar conclusion was also arrived previously by, for example, Monserrat et al. (1998).

Spectral analysis for atmospheric pressure also shows elevated energy during meteotsunamis as compared to that at background level during calm days. This elevation is demonstrated clearly in the spectral ratio plot where the oscillations are more energetic in the frequency greater than 0.01 $\min ^{-1}$. To show the frequency of the occurrence of meteotsunamis and to see how meteotsunamis follow atmospheric pressure perturbation, spectral filtering was performed for sea level and atmospheric pressure data. High-pass filter at a cut off frequency of $0.01 \mathrm{~min}^{-1}$ is applied for atmospheric pressure and a band-pass filter in frequency band of 0.01 - $0.2 \mathrm{~min}^{-1}$ for sea level. We give JU, where the largest meteotsunamis were recorded, as an example to demonstrate the correlation. Figure 3 shows the time series of the filtered signals centered at the aforementioned three events. We find that sudden changes in pressure appear to be rarer compared to a more frequent and smaller amplitude atmospheric pressure fluctuation, to excite and trigger meteotsunamis.

Finally, we analyze all meteotsunamis identified at JU during 2008 - 2014; most of the events are not destructive. We see that the amplitudes of the identified meteotsunamis follow closely with the amplitudes of atmospheric pressure perturbations. Figure 5 shows the correlation coefficient can be up to 0.8 , except in summer months when the meteorological condition is relatively stable. The rest of the months are known to be constantly affected by northeastern monsoons to various degrees, with the peak influence in winter months (DJF; Fig. 6). As a result of a more persistent atmospheric forcing in winter, the response in sea level is more prominent, demonstrated by a larger slope obtained in winter than in the other seasons (see Fig. 5). In addition, meteorological perturbations by arrivals of high latitude continental cold air masses are more frequent in winter and spring, which may result in more severe meteotsunamis (Fig. 6). Connecting meteotsunamis with synoptic patterns is going to be a subject of future research.

\section{DISCUSSION AND SUMMARY}

We have shown above that the occurrence of meteotsunamis in the northern coast of Taiwan is largely affected by direct atmospheric pressure perturbation. The analysis of meteorology and meteotsunamis reveals that forcing of atmospheric pressure fluctuations can be either sharp changes, low amplitude variations, or a combination of both. Findings also show the most influenced areas of meteotsunamis are JU and TP. Similar to other previous studies, the mechanism for enhancing meteotsunamis originated from sharp changes in atmospheric pressure has been established (e.g., Vilibić et al. 2004; Pattiaratchi and Wijeratne 2015). The generation through low amplitude high frequency pressure perturbation, however, has not been well understood (Vilibić et al. 2014).

PSDs show two dominant periods centered at 2.4 and $13.3 \mathrm{~min}$ at JU. Given the dimension of the JU harbor (720 $\mathrm{m}$ long, $360 \mathrm{~m}$ wide, and $4 \mathrm{~m}$ deep), the harbor resonance based on Merian's formula (Merian 1828) has a fundamental period of $7.7 \mathrm{~min}$, shorter than the identified 


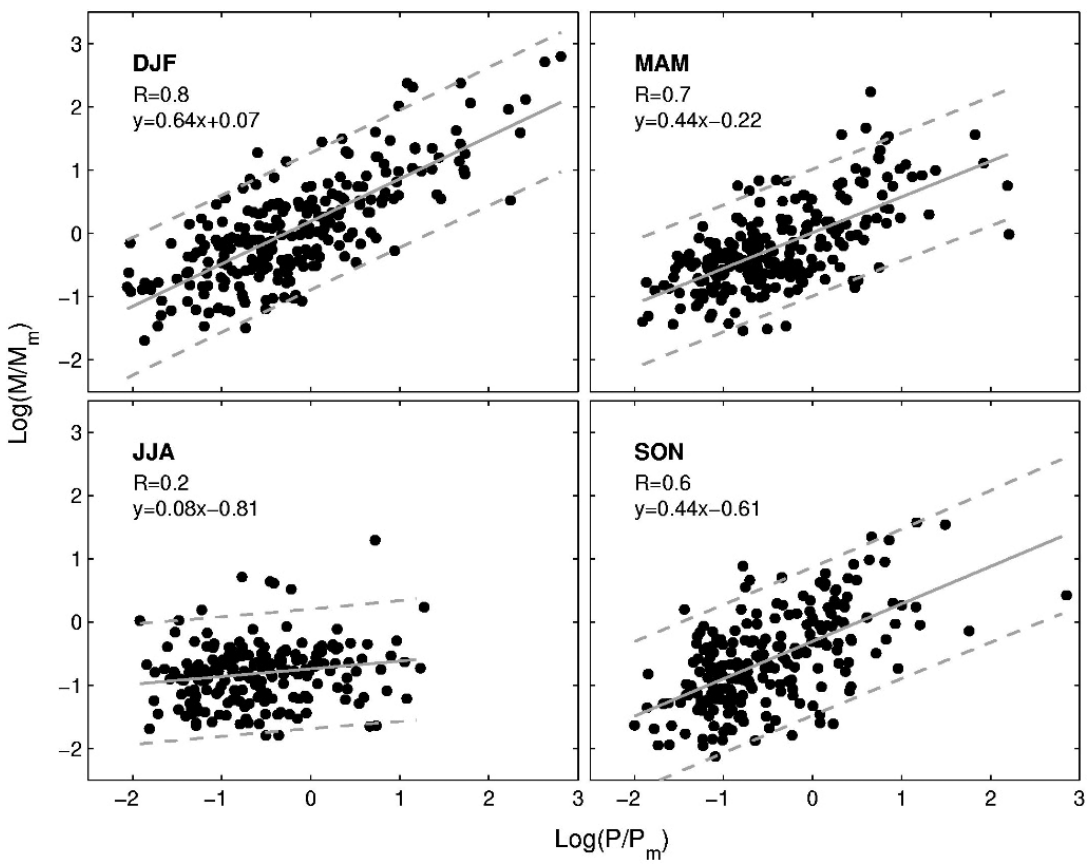

Fig. 5. Seasonal correlation of the daily mean amplitudes for high frequency filtered pressure $(\mathrm{P})$ at JU compared to the retrieved daily averaged amplitudes of meteotsunami $(M)$. Values are scaled by their respective means $\left(\mathrm{P}_{\mathrm{m}}\right.$ and $\left.\mathrm{M}_{\mathrm{m}}\right)$. The least squared linear regression fits are shown by the grey lines, with the $95 \%$ confidence level by the dashed lines.

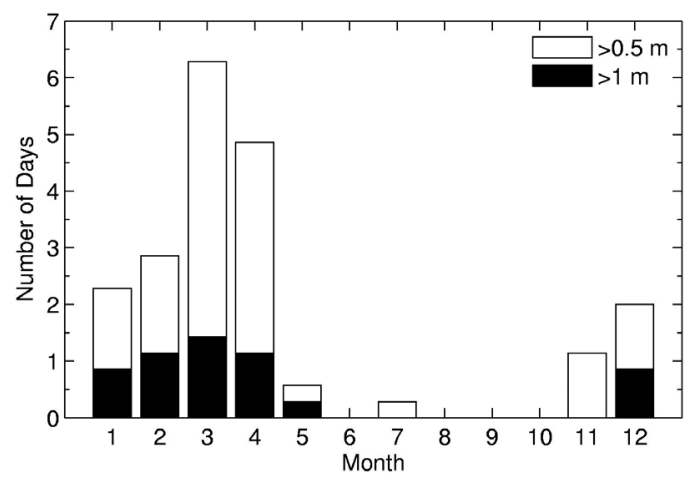

Fig. 6. Climatologically averaged (2008 - 2014) number of days in each month for the occurrence of meteotsunamis having amplitudes greater than 0.5 and $1 \mathrm{~m}$ at JU.

13.3 min period, and the harbor resonance is then ruled out. Greenspan and topographic resonances may be important in amplifying meteotsunamis and other long ocean waves. However, from spectral ratio analysis, we show that the peak at $13 \mathrm{~min}$ is likely due to the same generation as meteotsuinami in the open ocean, a conclusion that was arrived previously (e.g., Orlić et al. 2010).

In this study we show that atmospheric forcing (mainly continental cold air mass reported here) is likely responsible for the generation of meteotsunamis. Correlation analysis shows that $\sim 80 \%$ of the occurrence of meteotsunamis could be explained by atmospheric pressure perturbation. The correlation and response, however, are affected by different atmospheric situations, e.g., travel speed and incident angle, in meteotsunami generation. The established correlation between atmospheric forcing and meteotsunami generation then provides a way to quantify the occurrence of meteotsunamis, potentially useful for constructing a meteotsunami warning system. Future prediction can also be made by taking into account the changes of wind speeds in global warming scenarios (e.g., Vilibić et al. 2013). For example, it has been shown that the wind speed has been declined by more than 5\% in the last 30 years (Vautard et al. 2010). Extreme weathers have also been reported to be occurring more frequently (Škerlak et al. 2015), which favors the generation of a large amplitude meteotsunami.

Acknowledgements Special thanks are due to Central 
Weather Bureau, Taiwan for providing the high resolution ocean and meteorology data. We also thank the two anonymous reviewers for their insightful comments. This work was supported in part by a MOST grant 105-2111-M001-006-MY3 to Academia Sinica.

\section{REFERENCES}

De Jong, M. P. C. and J. A. Battjes, 2004: Low-frequency sea waves generated by atmospheric convection cells. J. Geophys. Res., 109, C01011, doi: 10.1029/2003JC001931. [Link]

Foreman, M. G. G., 1977: Manual for Tidal Heights: Analysis and Prediction, Pacific Marine Science Report, 7710, Institute of Ocean Sciences, Patricia Bay, Sidney, $58 \mathrm{pp}$.

Herbers, T. H. C., S. Elgar, and R. T. Guza, 1995: Generation and propagation of infragravity waves. J. Geophys.Res., 100, 24863-24872, doi: 10.1029/95jc02680. [Link]

Hibiya, T. and K. Kajiura, 1982: Origin of the Abiki phenomenon (a kind of seiche) in Nagasaki bay. J. Oceanogr. Soc. Jpn., 38, 172-182, doi: 10.1007/bf02110288. [Link]

Lu, M. M. and C. P. Chang, 2009: Unusual late-season cold surges during the 2005 Asian winter monsoon: Roles of Atlantic blocking and the central Asian anticyclone. $J$. Climate, 22,5205-5217, doi: 10.1175/2009JCLI2935.1. [Link]

Mecking, J. V., C. T. Fogarty, R. J. Greatbatch, J. Sheng, and D. Mercer, 2009: Using atmospheric model output to simulate the meteorological tsunami response to Tropical Storm Helene (2000). J. Geophys. Res., 114, C10005, doi: 10.1029/2009JC005290. [Link]

Merian, J., 1828: Ueber die Bewegung tropfbarer Flüssigkeiten in Gefässen (On the motion of drippable liquids in containers). Ph.D. Thesis, Basel, Schweighauser.

Monserrat, S., A. B. Rabinovich and B. Casas, 1998: On the reconstruction of the transfer function for atmospherically generated seiches. Geophys. Res. Lett., 25, 21972200, doi: 10.1029/98GL01506. [Link]

Monserrat, S., I. Vilibić, and A. B. Rabinovich, 2006: Meteotsunamis: Atmospherically induced destructive ocean waves in the tsunami frequency band. Nat. Hazards Earth Syst. Sci., 6, 1035-1051, doi: 10.5194/ nhess-6-1035-2006. [Link]

Orlić, M., 1980: About a possible occurrence of the Proudman resonance in the Adriatic. Thalassia Jugoslavica, 16, 79-88.

Orlić, M., D. Belušić, I. Janeković, and M. Pasarić, 2010: Fresh evidence relating the great Adriatic surge of 21 June 1978 to mesoscale atmospheric forcing. J. Geophys. Res., 115, C06011, doi: 10.1029/2009JC005777. [Link]
Pattiaratchi, C. B. and E. M. S. Wijeratne, 2015: Are meteotsunamis an underrated hazard? Phil. Trans. Roy. Soc. Lond. Math. Phys. Sci., 373, doi: 10.1098/ rsta.2014.0377. [Link]

Proudman, J., 1953: Dynamical Oceanography, John Wiley, 409 pp.

Rabinovich, A. B., 1997: Spectral analysis of tsunami waves: Separation of source and topography effects. J. Geophys. Res., 102, 12663-12676, doi: 10.1029/97JC00479. [Link]

Šepić, J. and I. Vilibić, 2011: The development and implementation of a real-time meteotsunami warning network for the Adriatic Sea. Nat. Hazards Earth Syst. Sci., 11, 83-91, doi: 10.5194/nhess-11-83-2011. [Link]

Šepić, J., I. Vilibić, and D. Belušić, 2009: Source of the 2007 Ist meteotsunami (Adriatic Sea). J. Geophys. Res., 114, C03016, doi: 10.1029/2008JC005092. [Link]

Škerlak, B., M. Sprenger, S. Pfahl, E. Tyrlis, and H. Wernli, 2015: Tropopause folds in ERA-Interim: Global climatology and relation to extreme weather events. J. Geophys. Res., 120, 4860-4877, doi: 10.1002/2014JD022787. [Link]

Thomson, R. E., A. B. Rabinovich, and M. V. Krassovski, 2007: Double jeopardy: Concurrent arrival of the 2004 Sumatra tsunami and storm-generated waves on the Atlantic coast of the United States and Canada. Geophys. Res. Lett., 34, L15607, doi: 10.1029/2007GL030685. [Link]

Vautard, R., J. Cattiaux, P. Yiou, J.-N. Thépaut, and P. Ciais, 2010: Northern Hemisphere atmospheric stilling partly attributed to an increase in surface roughness. Nat. Geosci., 3, 756-761, doi: 10.1038/ngeo979. [Link]

Vilibić, I. and G. B. Paklar, 2006: High-frequency atmospherically-induced oscillations in the middle Adriatic coastal area. Ann. Geophys., 24, 2759-2771, doi: 10.5194/angeo-24-2759-2006. [Link]

Vilibić, I., N. Domijan, M. Orlić, N. Leder, and M. Pasarić, 2004: Resonant coupling of a traveling air pressure disturbance with the east Adriatic coastal waters. J. Geophys. Res., 109, C10001, doi: 10.1029/2004JC002279. [Link]

Vilibić, I., H. Mihanović, and F. Charrayre, 2013: Assessing meteotsunami potential of high-frequency air pressure oscillations observed in the middle Adriatic. Nat. Hazards, 74, 217-232, doi: 10.1007/s11069-013-0865-x. [Link]

Vilibić, I., K. Horvath, N. Strelec Mahović, S. Monserrat, M. Marcos, A. Amores, and I. Fine, 2014: Atmospheric processes responsible for generation of the 2008 Boothbay meteotsunami. Nat. Hazards, 74, 25-53, doi: 10.1007/s1 1069-013-0811-y. [Link]

Welch, P. D., 1967: The use of fast Fourier transform for the estimation of power spectra: A method based on time averaging over short, modified periodograms. IEEE 
Trans. Audio Electroacoust., 15, 70-73, doi: 10.1109/ tau.1967.1161901. [Link]

Wijeratne, E. M. S., P. L. Woodworth, and D. T. Pugh,
2010: Meteorological and internal wave forcing of seiches along the Sri Lanka coast. J. Geophys. Res., 115, C03014, doi: 10.1029/2009JC005673. [Link] 